\title{
Conflict, International Response, and Forced Migration in Sub-Saharan Africa, 1980-2007*
}

\author{
Young Hoon Song \\ (Seoul National University)
}

〈CONTENTS〉

I . Introduction

II . Conceptualization of Forced Migration and Its Consequences

1. Conceptual Extension of Refugee to Forced Migrant

2. Conceptual Elements of Forced Migration in Conflicts

III. Humanitarian Responses and Refugee Flows
IV . Data, Variables, and Method

1. Unit of Analysis and Outcome Variables

2. Covariates

3. Estimating the Proportionality of Data

V . Empirical Results

1. Fractional Logit Analysis on Refugee Outflow

2. Fractional Logit Analysis on Refugee Inflow

VI. Conclusion

- Key words : conflict, international humanitarian response, refugee, internally displaced persons (IDPs), forced migration

\section{【ABSTRACT】}

This study investigates the effect of conflicts and international

\begin{abstract}
*The earlier version of this article was presented at the annual meeting of the Korean Association of International Studies held in the Institute of Foreign Affairs and National Security, December 9-10, 2011. This article is a part of my dissertation, which was completed at the Department of Political Science of the University of South Carolina with the financial support of the Walker Institute for International and Area Studies at the University of South Carolina. I thank Harvey Starr, Lee Walker, Katherine Barbieri, Zaryab Iqbal, and Roger Coate for their longtime support. I am also grateful to Byungha Lee and three anonymous reviewers for their constructive comments.
\end{abstract}

The Korean Journal of International Studies, Vol. 10, No. 1 (June 2012), 1-36.

(c) 2012 The Korean Association of International Studies 
humanitarian response on decisions of forcibly displaced people, including refugees and internally displaced persons (IDPs), about where to relocate in sub-Saharan Africa between 1980 and 2007. Although light has been shed on the plight of displaced people in studies on forced migration and international relations, no clear-cut answer exists as to what condition some displaced people relocate themselves within their country of origin while others seek refuge abroad. I argue that displaced people respond to violent conflict by making decisions, within their constrained freedom of choice, about where they go based on the expected levels of threat and humanitarian assistance and protection. The results of fractional logit analyses show that humanitarian operations where the United Nations High Commissioner for Refugees (UNHCR) is involved in a country of origin reduce the proportion of refugees fleeing from the country, while they are not statistically significant in terms of the proportion of refugees residing in a country of asylum. This mixed finding is closely related to the fact that sub-Saharan African countries recently have securitized refugees such that these countries are reluctant to receive refugees, producing a lot more IDPs than refugees.

\section{I . Introduction}

This study examines under what conditions a country will produce more refugees vis-á-vis internally displaced persons (IDPs). Specifically, I investigate the effects that international humanitarian response had on forced migrants' decisions to cross international borders in sub-Saharan African countries between 1980 and 2007. Traditionally, refugees and IDPs have been portrayed as by-products of conflict as well as passive victims in need of international assistance and protection. In reality, however, they can be both objects and subjects of political violence in forced migration crises. Displaced people may respond to violent conflict by making decisions, within their constrained freedom of choice, about whether to leave home and/or where to relocate based on the expected level of threat caused by conflict and expected level of humanitarian assistance and protection. 
At the end of 2009 , there were 43.3 million displaced people, including 8.8 million refugees, 1.6 million refugee-like persons, 4.8 million Palestinian refugees, and 27.1 million IDPs. ${ }^{1)}$ Compared to the numbers in the early 1980 s, the ratio of refugees to IDPs in contemporary forced migration crises has been dramatically reversed. When IDP data were first gathered in 1982, the ratio of refugees to IDPs was 10:12); however, by 1990, the ratio was reversed to $1: 1.5$, with 14.7 million refugees and 21.3 million IDPs. More recently, the ratio has increased to 1:3 in 2009. This reversal raises questions as to why some people are more likely to leave home than others and why some people are more likely to cross international borders.

If individuals leave home when facing violent conflict, they have to decide where to go. Those who cross international borders are expected to have better chances of having access to international assistance. However, even when faced with the same conditions, not all people cross international borders. The level of violence in a country of origin affects the likelihood that displaced people flee ${ }^{3)}$; at the same time, social, political, and economic conditions in neighboring countries also pull those individuals into those countries. ${ }^{4}$ On the other hand, neighboring countries often prevent those displaced people from moving into their territory because mass flight causes fundamental changes in individual lives and communal identities that can be

1) United Nations High Commissioner for Refugees (UNHCR), UNHCR Statistical Yearbook 2009 (Geneva, Switzerland: UNHCR, 2010); Internal Displacement Monitoring Centre (IDMC), Internal Displacement: Global Overview of Trends and Developments in 2009 (Geneva, Switzerland: IDMC, 2010). In the following analysis, this study does not include the number of Palestinian refugees, who are not among the populations under the responsibility of the UNHCR.

2) Roberta Cohen and Francis M. Deng, Masses in Flight: The Global Crisis of Internal Displacement (Washington, D.C.: Brookings Institute Press, 1998).

3) Jean-Paul Azam and Anke Hoeffler, "Violence against Civilians in Civil Wars: Looting or Terror?” Journal of Peace Research 33-4 (2002), pp. 461-485; Susanne Schmeidl, "Exploring the Causes of Forced Migration: A Pooled Time-Series Analysis, 1971-1990," Social Science Quarterly 78-2 (1997), pp. 284-308; Rudolph J. Rummel, Statistics of Democide: Genocide and Mass Murder Since 1990 (New Brunswick, NJ: Transaction Book, 1998); Harto Hakovirta, Third World Conflict and Refugeeism (Helsinki, Finland: The Finnish Society of Science and Letters, 1986).

4) Manuel Castells, The Rise of the Network Society (Cambridge, MA: Blackwell Publishers, 1996); Christian A. Davenport et al., "Sometimes You Just Have to Leave: Domestic Threats and Forced Migration, 1964-1989," International Interactions 29-1 (2003), pp. 2755; Douglas S. Massey et al., "Theories of International Migration: A Review and Appraisal," Population and Development Review 19-3 (1993), pp. 431-466. 
observed in terms of race, ethnicity, language, and religion. ${ }^{5)}$

Studies on pushing factors and pulling factors in forced migration crises have provided valid insights into forced migrants' movements, ${ }^{6}$ but the role of the international community has received less attention in empirical analyses. The level of humanitarian engagement in forced migration crises may play an important role as a preventive factor as well as a pulling factor. Since leaving one's home country is costly, displaced people are more likely to leave their countries of origin if there is a higher chance of having access to international assistance and protection in neighboring countries. ${ }^{7)}$ In this case, a large number of refugees are expected to depart for neighboring countries. However, if the international community is actively engaged with countries of origin, displaced people do not need to travel beyond international borders; rather, they are likely to stay inside their countries of origin because there they may have access to international assistance. Furthermore, if neighboring countries are reluctant to host refugees, displaced people are even less likely to go to those countries.

This study employs the fractional logit analysis because of the proportional attributes of the dependent variables, such as the proportions of refugee outflow and inflow. This study finds that humanitarian operations involving the United Nations High Commissioner for Refugees (UNHCR) in a country of origin reduce the proportion of refugees fleeing from the country. Contrary to expectation, the presence of internationalized conflict decreases the

5) Chaim D. Kaufman, Intervention in Ethnic, Ideological, and Colonial Wars: Opportunities, Options, and Constraints (Reston, VA: Sherman Kent School for Intelligence Analyses, 2004); Idean Salehyan, "Transnational Rebels: Neighboring States as Sanctuary for Rebel Groups," World Politics 59-2 (2007), pp. 221-242; Sue J. Nahm, "Rebels, Refugees, and War: Militarized Camps and Its Implications for Humanitarian Assistance in Time of War," a paper presented at the Annual Convention of the International Studies Association, Chicago, IL, USA, 28 February-3 March 2007.

6) Christian A. Davenport et al., op. cit:; Will H. Moore and Stephen M. Shellman, "Fear of Persecution: Forced Migration, 1952-1995," Journal of Conflict Resolution 43-5 (2004), pp. 723-745; Eric Neumayer, "Bogus Refugees? The Determinants of Asylum Migration to Western Europe,” International Studies Quarterly 49-3 (2005), pp. 389-409; Zaryab Iqbal, "The Geo-Politics of Forced Migration in Africa, 1992-2001," Conflict Management and Peace Science 24-2 (2007), pp. 105-119.

7) Will H. Moore and Steve Shellman, "Refugee or Internally Displaced Person? To Where Should One Flee?" Comparative Political Studies 39-5 (2006), pp. 599-633; Sarah K. Lischer, Dangerous Sanctuaries: Refugee Camps, Civil War, and the Dilemmas of Humanitarian Affairs (Ithaca, NY: Cornell University Press, 2005). 
proportion of refugees. This can be explained by the fact that sub-Saharan African countries recently have securitized refugees such that they are reluctant to host refugees, and thus, conflicts have produced a lot more IDPs than refugees. The presence of genocide and politicide generates appeals to neighboring countries to receive more refugees. ${ }^{8}$ On the other hand, humanitarian operations are not statistically significant in terms of the refugee proportion residing in a country of asylum. Violent conflict in a country of asylum does not provide displaced people from other countries with the opportunity to resettle in that country, leading to the decrease of the proportion of refugee inflow to that country.

This article is organized as follows. The next section addresses issues of extending the concept of refugee to forced migrant as well as conceptual elements of forced migration. The third section presents testable hypotheses on the relationship between humanitarian response and refugee flows. The fourth section describes data and variables included in empirical analyses, while the fifth presents the methodological issues in dealing with the proportionality of refugee flow data. The empirical results of fractional logit analyses are reported in the sixth section, followed by the conclusion with suggestions and implications for future study.

\section{II . Conceptualization of Forced Migration and Its Consequences}

\section{Conceptual Extension of Refugee to Forced Migrant}

In studying contemporary forced migration crises, it is important but difficult to define the population of interest of an analysis. Conventionally,

8) Genocide and politicide events involve the promotion, execution, and/or implied consent of sustained policies by governing elites or their agents, or in the case of civil war, military actions among contending authorities that result in the deaths of a substantial portion of a communal group or politicized non-communal group (Barbara Harff, "No Lessons Learned from the Holocaust? Assessing the Risks of Genocide and Political Mass Murder Since 1955," American Political Science Review 97-1 [2003], pp. 57-74). In the case of genocide and politicide, authorities physically exterminate enough, though not necessarily all, members of a target group so that it can no longer pose any conceivable threat to their rule or interests. 
refugees have received much attention in international relations studies because it is easy to distinguish refugees recognized by the 1951 Convention from other displaced people. However, the traditional concept of refugee does not reflect realities of the world today. Likewise, the international community has interpreted the concept very conservatively, marginalizing those who demonstrate the same needs as refugees. Hence, the social concept of refugee should be extended to include other refugee-like forced migrants such as IDPs.

In extending the concept of refugee, three premises of the definition of refugee developed in the 1951 Convention - the centrality of the individual, state sovereignty, and security - must be appropriately addressed. The centrality of the individual suggests that a legal entitlement enables a person who has moved to avoid the risk of serious human rights abuse to make claims on the international community. In other words, refugee status must be given to an individual rather than a group of individuals. Second, from its origin, the concept of refugee implies that a government has absolute authority over its citizens. Third, the international refugee regime recognizes that refugee flows may jeopardize national and international security.

From the positive legalist perspective, Hathaway argues against the conceptual extension. ${ }^{9)}$ He contends that the broader framework of forced migration may fail to explain the specificity of refugees' circumstances, which are defined by social disfranchisement coupled with the unqualified response of the international community. His legal approach is rooted in Hannah Arendt's observation:

Not the loss of specific rights, then, but the loss of a community willing and able to guarantee any rights whatsoever, has been the calamity that has befallen ever-increasing numbers of people. Man, it turns out, can lose all so-called Rights of Man without losing his essential quality as man, his human dignity. Only the loss of a polity itself expels him from humanity. ${ }^{10)}$

In addition, he maintains that, by focusing on the phenomenon itself, forced

9) James C. Hathaway, "Forced Migration Studies: Could We Agree Just to Date?" Journal of Refugee Studies 20-3 (2007), pp. 349-369.

10) Hannah Arendt, The Origins of Totalitarianism (New York: Harcourt, 1966), p. 297. 
migration studies are less likely to address the personal predicaments, needs, and rights of refugees themselves. These arguments are reasonable to some extent in that, by broadening the concept, it becomes difficult to distinguish refugees from those who do not migrate under the same human rights violations.

This approach, however, is problematic in three respects. First, the refugee defined by the 1951 Convention is perceived as an identifiable individual among specific groups in a specific area at a certain time. The philosophical underpinnings of the definition have served well for individuals in Western Europe targeted for persecution. ${ }^{11)}$ However, most contemporary IDPs and refugee-like displaced persons do not belong to this category. Second, numbers matter. If there are a small number of refugees, a host country will allow them to enter its territory following the principle of the 1951 Convention. If the group reaches an unmanageable size, refugees turn out to be a burden or a threat; then, their individual rights are likely to be denied by the receiving government. Third, this textual approach focuses on specific persecution, which is the concept developed in light of the rise of communism. ${ }^{12)}$ The focus should extend to the "well-founded fear" so that the concept of the forced migrant can encompass many other reasons for displacement. By doing so, those displaced people who have been marginalized for a long time in international relations fall within a category for both humanitarian operation and scientific analysis.

Refugee-related issues are also inherently political, and therefore, humanitarian actions influence and are influenced by national and international politics. While these moving entities of displaced people have existed throughout history, the current concept of refugee was invented in the twentieth century by sovereign states. The most controversial issue is how best to secure the rights of refugees. For communitarians, only the political community can realize the best interests of its members because the international system consists of sovereign states, not individual human

11) Bridget Hayden, "What's in a Name? The Nature of the Individual in Refugee Studies," Journal of Refugee Studies 19-4 (2006), pp. 471-487; B. S. Chimni, "The Birth of a 'Discipline': From Refugee to Forced Migration Studies," Journal of Refugee Studies 22-1 (2009), pp. 11-29; Emma Haddad, The Refugee in International Society: Between Sovereigns (New York: Cambridge University Press, 2008).

12) Howard Adelman and Susan McGrath, "To Date or To Marry: That Is the Question," Journal of Refugee Studies 20-3 (2007), pp. 376-380. 
beings ${ }^{13)}$ For cosmopolitans, on the other hand, all human rights are based on the natural law to which sovereign states are subject to yield their power in order to achieve universal human rights. State sovereignty means not only power but also the responsibility to respect human rights of all citizens living within a sovereign territory. ${ }^{14}$

Communitarians and cosmopolitans concentrate on the rights of people who have crossed international borders. The state sovereignty tradition has provided a foundation for the distinction between refugees and IDPs. Yet, it has been increasingly challenged since the mid-1990s when a series of international negotiations to achieve an international IDP regime began. The Guiding Principles on Internal Displacement in 1997 offers a "soft law" framework for applying existing human rights and international humanitarian law to help IDPs. International humanitarian agencies have developed a collaborative framework within which to share the responsibility for the protection of IDPs. ${ }^{15)}$ In this process, however, international efforts to help IDPs have reinforced state sovereignty because, with increasing concerns about international migration, Northern states find ways to enhance their border control while intervening to contain the outflow of a large number of displaced people from Southern states. The "universal human rights" of a refugee cannot be universal if other displaced people stay in their countries of origin, and sovereign states keep violating their "universal obligations" to secure the well-being of all citizens.

Finally, the concept of refugee is closely related to the concept of security in international relations. It can be asked why sovereign states sign up for the refugee protection regime and put their internal affairs under international scrutiny. One reason is because refugees are considered to be deviants of the international sovereign system, and they are likely to destabilize the system. Refugees and IDPs have been manipulated as resources of war by both state and non-state armed groups ${ }^{16}{ }^{16}$ Moreover, in post-conflict situations, refugees

13) Michael Walzer, Spheres of Justice (New York: Basic Books, 1983).

14) Catherine Phuong, The International Protection of Internally Displaced Persons (New York: Cambridge University Press, 2004).

15) Thomas G. Weiss and David A. Korn, Internal Displacement: Conceptualization and Its Consequences (New York: Oxford University Press, 2006).

16) Stephen John Stedman and Fred Tanner, Refugee Manipulation: War, Politics, and the Abuse of Human Suffering (Washington, DC: Brookings Institution Press, 2003); Myron 
and IDPs are considered to be potential "spoilers" in attempts to develop peace-building initiatives. Lischer claims that refugee crises may or may not exacerbate national and international security depending on the different origins of the refugee crises; the policy of the receiving country to secure its border; and the intended and unintended activities of external actors, including humanitarian agencies. ${ }^{17)}$ Thus, the concept of refugee should involve both conventional refugees and IDPs, both of whom affect security around humanitarian camps and nations.

The concepts of individuality, sovereignty, and security are interconnected in the definition of refugee; but none of these can be appropriately addressed without considering the others. Although the conceptual extension may weaken the centrality of the existing refugee concept, the broader concept of forced migrant can include other individuals such as IDPs, whose tragedies in life and roles in politics have not been fully recognized. The extension of the concept may offer useful information to develop analytical frameworks and policy solutions for complex humanitarian emergencies.

\section{Conceptual Elements of Forced Migration in Conflicts}

The conceptual extension of forced migration creates a subset of categories that allows for comparative analysis, while the extension makes it difficult to define the population of interest for empirical study. In an attempt to extend the population under consideration to include IDPs, I describe forced migration as follows:

a process of mass population movements in situations of conflict where civilians are coerced, directly and/or indirectly, by one or more armed groups competing over territory or government, to migrate despite limited resources and limited opportunities for assistance and protection.

For analytical concerns, this definition consists of five conceptual elements.

Weiner, "Security, Stability, and International Migration," International Security 17-3 (1992), pp. 91-126; Gil Loescher, Beyond Charity: International Cooperation and the Global Refugee Crisis (New York: Oxford University Press, 1993).

17) Sarah Kenyon Lischer, op. cit. 
First, forced migration is a process in which acting agents of government and armed groups, the international community, and forced migrants interact simultaneously and in sequence. Forced migration is not only a humanitarian incident but also a social, economic, and political phenomenon that reveals the probabilistic causal relationship among the components of the concept. The concept of forced migration as a process reflects the growing observation that people may or may not have their destination in mind before they leave and that they are most likely to find a destination in the middle of movement. In other words, people respond, even in very constrained opportunities, to the triadic relationship of their countries of origin, their countries of destination, and the international community.

Second, "force" is the violence of conflict carried out by one or more armed groups in the competition for territory or government. That is, this definition focuses on population movement as a result of armed conflict, including genocide, political persecution, civil war, and international wars. ${ }^{18)}$ Government and armed groups have deliberately targeted civilians in order to mobilize the support of their constituencies or to exploit resources that targeted groups hold. Reportedly in civil wars and other internal conflicts, governments and armed groups use violence both to prevent the defection of specific groups and to induce their compliance. ${ }^{19)}$ This violence endangers the lives and security of individuals, and it becomes an imminent force. Nevertheless, not all of these people leave home (or country) in the face of violent conflict.

Third, the responses of neighboring states and the international community affect the decision-making processes of forced migrants. International humanitarianism is not new in the history of international relations. It has

18) Patrick Ball et al., "Killings and Refugee Flow in Kosovo, March-June 1999: Analysis and Conclusions," a report to the International Criminal Tribunal for the Former Yugoslavia (Washington, DC: American Association for the Advancement of Science, 2002); Suanne Schmeidl, op. cit:; Myron Weiner, "Bad Neighbors, Bad Neighborhoods: An Inquiry into the Causes of Refugee Flows," International Security 21-2 (1996), pp. 5-42; Andrew R. Morrison and Rachel A. May, "Escape from Terror: Violence and Migration in PostRevolutionary Guatemala," Latin American Research Review 29-2 (1994), pp. 111-133; Will H. Moore and Stephen M. Shellman (2006), op. cit.

19) Stathis N. Kalyvas, The Logic of Violence in Civil Wars (New York: Cambridge University Press, 2006); Mark Irving Lichbach, The Rebel's Dilemma (Ann Arbor, MI: The University of Michigan Press, 1995). 
evolved along with the evolution of international conflict and cooperation. International humanitarian agencies can provide displaced people with better opportunities to be secure in many ways, especially when governments do not have the willingness and capacity to do so. But sometimes a government and armed groups exploit international humanitarian efforts to maximize their own interests and influence. Thus, both conflict and humanitarian responses should be taken into consideration simultaneously in order to draw a plausible causal inference.

Fourth, the concept of the forced migrant includes both refugees, who are recognized by the 1951 Convention, and IDPs, who are not. Forced migrants are assumed to make decisions based upon their expectations of both being victimized and being secure, meaning that they hold their varying degrees of freedom of choice. Notably, few migrants exercise either maximum choice or no choice. As Van Hear states, "Almost all migration involves some kind of compulsion; at the same time almost all migration involves choices. ${ }^{20)}$ Most forced migrants are projected somewhere between the ends of the maximumchoice and no-choice continuum of forced migration. Therefore, given the limited options of "exit," "voice," and "loyalty,"21) forced migrants play different roles under different circumstances at different stages of their movement.

Fifth, forced migration is taken seriously when it is mass flight rather than individual migration. Individual migration, such as economic migration, often takes place based upon migrants' anticipation about where to go. In mass flight, however, forced migrants do not know when and where they will end their travel. With incomplete information, they move as a group to seek safety. Their movement as a mass can alter the process and outcome of a conflict. The mass movement of displaced people often intensifies the tension with the local population in regards to the competition for resources, and it may diffuse the insecurity within a country of origin to an asylum country. The situation gets much worse when forced migrants turn into refugee fighters or a recruitment pool for terrorist or rebel groups.

20) Nicholas Van Hear, New Diasporas: The Mass Exodus, Dispersed and Regrouping of Migrant Communities (Seattle, WA: University of Washington Press, 1998), p. 42.

21) Albert O. Hirshman, Exit, Voice, and Loyalty: Responses to Decline in Firms, Organizations, and States (Cambridge, MA: Harvard University Press, 1970). 


\section{Humanitarian Responses and Refugee Flows}

According to social liberalism and political liberal internationalism, international humanitarian operations affect forced migration on two levels. First, international humanitarian operations in a country may affect the policy choice of the government of the country. Although sovereign states created the international refugee regime, the international regime constrains state sovereignty and so does the evolving international IDP regime. Supporting the responsibility of the international community for displaced persons regardless of whether persons have a legal right to international assistance, many liberal scholars argue that the presence of intergovernmental humanitarian agencies such as UNHCR is likely to draw international attention, and the government of the country cannot avoid damaging its legitimacy if it were to take military actions against its civilians. ${ }^{22)}$ In other words, a higher level of international humanitarian commitment is likely to decrease the likelihood that government and armed groups will use violent means against civilians.

At the individual level, the existence of humanitarian advocacy groups and inter-governmental organization (IGO) agencies in a country is likely to increase individuals' expectations that they can be assisted and protected. In contrast to voluntary economic migrants, each individual makes his or her decision based on incomplete information about the likelihood of being victimized and the likelihood of being saved. ${ }^{23)}$ Especially in the case of abrupt violent incidents, individuals move or stay with other people without a second thought about their destination. If the international community launches humanitarian operations, however, individuals are likely to move into the area under operations and are expected to return soon with the help of the international community.

22) Emma Haddad, op. cit.; Alan Dowty and Gil Loescher, "Refugee Flows as Grounds for International Actions," International Security 21-1 (1966), pp. 43-71; Roberta Cohen and Francis M. Deng, op. cit.; Jack Donnelly, Universal Human Rights in Theory and Practice, 2nd ed. (Ithaca, NY: Cornell University Press, 2003); Matthew J. Gibney, The Ethics and Politics of Asylum: Liberal Democracy and the Response to Refugees (New York: Cambridge University Press, 2004).

23) Christian A. Davenport et al., op. cit.; Will H. Moore and Stephen M. Shellman (2006), op. cit. 
In contrast to the expectation of social liberals, humanitarian actions often bring about negative consequences on forced migration. First, government and armed groups abuse humanitarian resources to increase their influence on civilians. ${ }^{24)}$ Humanitarian aid turns into the resources for government or armed groups to solve the "Rebel's Dilemma," ${ }^{25}$ in which both parties try to increase loyalty among civilians and prevent their defection. Second, when donor governments have political interests in forced migration crises, they either provide humanitarian aid through a bilateral process or want to hold agencies accountable to them rather than the displaced people. ${ }^{26)}$ However, a donor country's political interests also constrain the policy alternatives of recipient countries.

That is, forced migration is not a by-product of a conflict, but a complex, interactive political process among fighting parties, humanitarian agencies, and moving people. In making decisions to stay or leave, people not only consider threat perception, which is posed by root causes, but they also count on information regarding whether they are likely to be secure with the help of humanitarian agencies. This can be expressed as follows:

$$
\operatorname{Pr}(\text { Forced Migration })_{i t}=\alpha+\delta(\text { Threat })_{i t}+\gamma(\text { Humanitarian Response })_{i t}+\beta X_{i t}+\mu
$$

where the $\operatorname{Pr}($ Forced Migration $)$ it represents the probability that an individual flees; the (Threat) it means the perceived likelihood that an individual is victimized by military actions of government or armed group(s) in situations of conflict; the (Humanitarian Opportunity)it stands for the expectation that an individual can get access to international humanitarian assistance; and the $X_{i t}$ indicates other preconditions in a country of origin.

In sum, international humanitarian engagement in a country of origin puts higher costs on the fighting parties should they use violence against civilians.

24) Sarah K. Lischer, "Collateral Damage: Humanitarian Assistance as a Cause of Conflict," International Security 28-1 (2003), pp. 79-109.

25) Mark Irving Lichbach, op. cit.

26) Steven D. Roper and Lilian A. Barria, "Burden Sharing in the Funding of the UNHCR: Refugee Protection as an Impure Public Good," Journal of Conflict Resolution 54-4 (2010), pp. 616-637; Raimo Vayrynen, "Funding Dilemmas in Refugee Assistance: Political Interests and Institutional Reforms in UNHCR," International Migration Review 35-1 (2010), pp. 143-167. 
Military actions against civilians under these conditions are likely to damage the credibility of government and/or armed groups, so more individuals can be allowed to access international assistance. Accordingly, the decreasing perceived probability of being attacked keeps people from leaving their country by decreasing the perceived costs of staying within the country. Therefore, a larger portion of IDPs over refugees will be observed. On the other hand, if individuals experience limited access to international assistance in their countries of origin, displaced people are more likely to leave their countries. Consequently, the number of refugees over IDPs is expected to increase.

Thus, this study proposes the following testable hypotheses.

Hypothesis 1: A higher level of humanitarian expenditures in a country of origin will be likely to reduce the likelihood of a larger refugee outflow.

Hypothesis 2: The existence of UN peacekeeping operations in a country of origin will reduce the likelihood of a larger refugee outflow.

The international community may not be allowed to initiate humanitarian field operations in countries of origin while it may provide assistance and protection to those who leave their countries of origin for neighboring countries. The host government is likely to obtain a good reputation by its cooperation in humanitarian responses to the influx of refugees. In this situation, the refugee flow will take place on a large scale. However, hosting a large number of refugees is also costly to countries with very limited resources, as is the case with most sub-Saharan African countries.

If the level of international engagement diminishes, host governments consider refugee inflow a serious threat to national and international security. Then, they are likely to adopt a policy that would prevent displaced people from moving into their territory and/or that would confine those who have already crossed international borders in places close to the international borders of their countries of origin without recognizing those displaced people as refugees, leading to a small portion of refugees over IDPs. For example, since the late 1990s, governments of Tanzania and Kenya have repeatedly closed their country borders due to the decreasing level of international humanitarian assistance to refugees residing in their territories. Even the two very generous refugee-hosting governments become very 
sensitive to international humanitarian responses because of their limited national capacities.

Thus, the following testable hypotheses are proposed:

Hypothesis 3: A higher level of humanitarian expenditures in a bordered country will increase the likelihood of a larger refugee inflow from a country of origin to a host country.

Hypothesis 4: The existence of UN peacekeeping operations in a bordered country will increase the likelihood of a larger refugee inflow to that host country from a country of origin.

\section{Data, Variables, and Method}

\section{Unit of Analysis and Outcome Variables}

The unit of analysis is a country year, covering 41 sub-Saharan African countries between 1980 and 2007. Eritrea and Namibia are included in the analysis since 1993 and 1990, respectively. Countries with population under 500,000, including Cape Verde, Sao Thome and Príncipe, and Seychelles, are excluded from the analysis. In addition, Comoros, Madagascar, and Mauritius are additionally excluded because these island countries are not considered bordered countries.

The outcome variable of this study is the ratio of refugees to the total forced migrants in a given country year:

$$
(\text { Proportion of refugee flow })_{i t}=\frac{(\text { Refugee flow })_{i t}}{(\text { FM flow })_{i t}}
$$

in which $(F M \text { flow })_{i t}$ represents the sum of refugees flow (Refugees $i^{-}$ Refugees $\left._{i t-1}\right)$ and IDP flow (IDPs $\left.s_{i t}-I D P s_{i t-1}\right)$ for the $i$ th country in the $t$ th year. The outcome variable of interest is proportional data ranging from 0 to 1. The value of 0 indicates that no new refugee is observed while there are new IDPs, and the value of 1 indicates that all newly displaced people cross international borders. The refugee data were collected from the UNHCR Online Population Statistical Database and the IDP data were collected from 
the World Refugee Survey and the Internal Displacement Monitoring Center.

For analytical purposes, two indicators are used. First, the proportion of refugee outflow is calculated by:

$$
(\text { Proportion of refugee outflow })_{i t}=\frac{(\text { Refugee outflow })_{i t}}{(\text { Refugee outflow })_{i t}+(\text { IDP flow })_{i t}}
$$

which is the ratio of refugees to the total number of refugees and IDPs that a country of origin displaces in a given year. For example, the score of the proportion of refugee outflow for Sudan in 2004 is 0.09 because it produced new 125,000 refugees and new 1,200,000 IDPs. Thus, the score is calculated by $\left(\frac{125}{125+1200}\right)$.

Second, the proportion of refugee inflow is calculated by:

$$
(\text { Proportion of refugee inflow })_{i t}=\frac{(\text { Refugee inflow })_{i t}}{(\text { Refugee inflow })_{i t}+(\text { Refugee inflow })_{i t}}
$$

which is the ratio of refugee inflow to the sum of refugee inflow and IDP flow residing in country $i$ in a given year $t$. For instance, Sudan in 2007 scores its lowest point at .032 , calculated by $\left(\frac{21}{21+645}\right)$ because 21,000 refugees newly entered to Sudan while 645,000 IDPs were newly displaced in Sudan. Sudan is hosting refugees while it is simultaneously producing refugees and a great number of IDPs. This is a general pattern of forced migration in subSaharan Africa, in which countries experience net immigration-emigration shifts and displaced people move to somewhere inside their countries of origin or bordered countries.

In sub-Sahara Africa, a larger proportion of refugees is not necessarily associated with a larger number of refugees. Thus, the following dynamics should be taken into consideration. First, many sub-Saharan African countries produce refugees while at the same time hosting refugees. Twenty-eight countries not only produced refugees but also hosted refugees without producing new IDPs for 67 country years. Second, refugees are more likely to be allowed to come into a country of asylum when the number of refugees is relatively small. If the number of displaced people is growing, neighboring countries are likely to securitize the refugee crises and keep displaced people from moving into their territories, leading to a lower share of refugees among 
the total forced migrants. Third, most refugees relocate themselves in bordered countries, and once a country has produced IDPs, the number of IDPs is much larger than the number of refugees.

The binary variable of Forced Migration is generated in order to deal with the selection effect. Since forced migration becomes consequential when it takes place on a large scale, the variable is coded as 1 if there are at least 500 forced migrants and 0 otherwise. Only the countries that displace a significant number of people can have the chance to produce refugees.

\section{Covariates}

\section{1) Humanitarian Assistance and Protection}

The degree of humanitarian assistance in a country is measured by the UNHCR's annual expenditure in US $\$ 1,000$ for humanitarian operation in the country. The data were collected from the annual reports of UNHCR to the UN General Assembly (UN Doc. A/36-63/12, 1981-2008). The UN peacekeeping is a proxy to measure the influence of humanitarian protection on forced migration, which is coded as 1 if there is an ongoing UN peacekeeping operation in a given country year and 0 otherwise.

The international humanitarian engagement in neighboring countries is expected to affect the decision-making of displaced people. While displaced people seek refuge outside of their countries of origin, not all neighboring countries will be supportive of those refugees. As long as there is at least one country in which displaced people expect to get assistance and protection, they are likely to cross international borders. This study does not concentrate on the specific destination of refugees. Because this study attempts to evaluate the impact of humanitarian operations in neighboring countries on refugee outflow from a country of origin and inflow from neighboring countries, the variable of neighbor humanitarian assistance is generated by averaging the UNHCR's annual expenditure in all bordered countries. The neighbor humanitarian protection variable is generated by coding it as 1 if there is an ongoing UN peacekeeping operation in at least one bordered country and 0 otherwise. 


\section{2) Push and Preventive Factors: Conflict, State Failure, and Economic Performance}

Violent conflict, state failure, and economic insecurity in a country of origin play roles not only in displacing people but also in pushing displaced people outside their countries of origin. The international conflict is coded as 1 if there is an interstate conflict or at least one other country intervenes in an internal conflict and 0 otherwise. The internal conflict is coded as 1 if there is an internal conflict. Both variables are generated using the UCDP/PRIO Armed Conflict Dataset. ${ }^{27)}$ If there is genocide or politicide, the variable of genocide/politicide is coded as 1 and 0 otherwise. ${ }^{28)}$ The binary variable of state failure is coded as 1 if a central government is collapsed, which is scored -77 in the Polity IV project ${ }^{29)}$ Economic performance of a country is measured by the log of GDP per capita extracted from the World Development Indicators, the World Bank.

On the other hand, if neighboring countries experience conflict and state failure or there are not many economic opportunities in those countries, displaced people are less likely to move into the countries in favor of staying within their country of origin. The neighbor international conflict is coded as 1 if there is an interstate or internationalized conflict in bordered countries. The neighbor internal conflict is coded as 1 if there is an internal conflict in bordered countries and 0 otherwise, while the neighbor genocide/politicide is coded as 1 if there is a genocide or politicide in bordered countries. The neighbor state failure is coded as 1 if any bordered country is a failed country and 0 otherwise. The economic performance of bordered countries, neighbor GDP per capita, is measured by averaging the GDP per capita of all bordered countries. Descriptive statistics are in Table 1.

27) Nils Petter Gleditsch et al., “Armed Conflict 1946-2001: A New Dataset," Journal of Peace Research 39-5 (2002), pp. 615-637.

28) Barbara Harff, op. cit.

29) Harvey Starr, "Introduction to the CMPS Special Issue on Failed States," Conflict Management and Peace Science 25-4 (2008), pp. 281-284; Zaryab Iqbal and Harvey Starr, "Bad Neighbors: Failed States and Their Consequences," Conflict Management and Peace Science 25-4 (2008), pp. 105-109. 
Table 1. Descriptive Statistics

\begin{tabular}{|c|c|c|c|c|c|}
\hline Variable & Obs. & Mean & Std. Dev. & Min. & Max. \\
\hline Proportion of refugees to FM outflow & 1084 & 0.177 & 0.369 & 0 & 1 \\
\hline Proportion of refugees to FM inflow & 1084 & 0.291 & 0.449 & 0 & 1 \\
\hline Log of UNHCR expenditure & 1125 & 5.406 & 4.227 & 0 & 11.566 \\
\hline UN Peacekeeping & 1125 & 0.066 & 0.248 & 0 & 1 \\
\hline Log of UNHCR expenditure $t_{t-1}$ & 1084 & 5.333 & 4.233 & 0 & 11.566 \\
\hline UN Peacekeeping ${ }_{t-1}$ & 1084 & 0.063 & 0.243 & 0 & 1 \\
\hline International conflict & 1125 & 0.068 & 0.253 & 0 & 1 \\
\hline Internal conflict & 1125 & 0.198 & 0.399 & 0 & 1 \\
\hline Genocide/Politicide & 1125 & 0.052 & 0.223 & 0 & 1 \\
\hline State failure & 1125 & 0.048 & 0.214 & 0 & 1 \\
\hline Log of GDP per capita & 1057 & 5.970 & 0.938 & 4.131 & 8.898 \\
\hline Border straightness & 1069 & 0.031 & 0.014 & 0.003 & 0.072 \\
\hline Ethnic fractionalization & 985 & 52.486 & 28.473 & 0.5 & 100 \\
\hline Log of UNHCR expenditure (NB) & 1125 & 7.437 & 3.101 & 0 & 11.211 \\
\hline UN peacekeeping (NB) & 1125 & 0.219 & 0.414 & 0 & 1 \\
\hline Log of UNHCR expenditure (NB $\left.{ }_{t-1}\right)$ & 1084 & 7.369 & 3.133 & 0 & 11.211 \\
\hline UN peacekeeping $\left(\mathrm{NB}_{t-1}\right)$ & 1084 & 0.208 & 0.406 & 0 & 1 \\
\hline International conflict (NB) & 1125 & 0.236 & 0.425 & 0 & 1 \\
\hline Internal conflict (NB) & 1125 & 0.548 & 0.498 & 0 & 1 \\
\hline Genocide/Politicide (NB) & 1125 & 0.180 & 0.384 & 0 & 1 \\
\hline State failure (NB) & 1125 & 0.211 & 0.408 & 0 & 1 \\
\hline Log of GDP per capita (NB) & 1124 & 5.995 & 0.665 & 4.628 & 8.271 \\
\hline FM outflow $t-1$ & 1043 & 58.860 & 259.776 & 0 & 3500 \\
\hline FM inflow ${ }_{t-1}$ & 1043 & 58.353 & 239.706 & 0 & 3500 \\
\hline
\end{tabular}

\section{Estimating the Proportionality of Data}

The methodological concern of this study is modeling the dependent variable with proportional values. Examples of fractional response variables in political science research include the ratio of success to the total number of trials, ${ }^{30)}$ the percentage of time a police officer avoids his or her duty, ${ }^{31)}$ the

30) Bradley Palmquist, "Analysis of Proportion of Data," a paper presented at the 1999 Annual Meeting of the Political Methodology Society, College Station, TX. 
location of a party's ideal point, ${ }^{32)}$ voter turnout ratio, ${ }^{33)}$ and ratio of refugees. ${ }^{34)}$ Given that there is no statistically significant evidence of a sample selection problem, this study uses a fractional logit model, using STATA $11.0 \mathrm{I} / \mathrm{C}$, which was developed by Papke and Wooldridge ${ }^{35)}$ and Wooldridge ${ }^{36)}$ in order to model the dependent variables with fractional or proportional values in the unit interval, i.e., $y_{i} \in[0,1]$.

A fractional logit model overcomes several problems encountered when other methods are used with fractional response variables. ${ }^{37)}$ The OLS regression does not guarantee predictions fall within a unit interval. Logit regression requires arbitrary adjustments for all observations taking on boundary values 0 or 1 . However, fractional logit estimation improves upon previously used statistical methods because it only requires that the conditional mean be specified correctly to obtain consistent parameter estimates and it allows for direct estimation of the desired fractional response variable. $^{38)}$

Additionally, this study reports the results of the zero-inflated beta regression model (ZINB) in order to check the robustness. The ZINB regression model nests a beta regression model and a selection equation model, modeling the dependent variable of the proportion $[0,1)$. The results in this study are almost the same as those of the fractional logit regression.

31) John Brehm and Scott Gates, "Donut Shops and Speed Traps: Evaluating Models of Supervision on Political Behavior," American Journal of Political Science 37-2 (1993), pp. 551581.

32) Walter R. Mebane, "Coordination, Moderation, and Institutional Balancing in American Presidential House Election," American Political Science Review 94-1 (2000), pp. 37-57.

33) G. Bingham Powell, "American Voter Turnout in Comparative Perspective," American Political Science Review 80-1 (1986), pp. 17-43.

34) Will H. Moore and Stephen M. Shellman (2006), op. cit.

35) Leslie E. Papke and Jeffrey M. Wooldridge, "Econometric Methods for Fractional Response Variables, with an Application to 401(k) Plan Participation Rate," Journal of Applied Econometrics 11-6 (1996), pp. 619-632.

36) Jeffrey M. Wooldridge, Econometric Analysis of Cross Section and Panel Data (Cambridge, MA: MIT Press, 2002).

37) Philip Paolino, "Maximum Likelihood Estimation of Models with Beta-Distributed Dependent Variables," Political Analysis 9-4 (2001), pp. 325-346.

38) Leslie E. Papke and Jeffrey M. Wooldridge, op. cit.; Jeffrey M. Wooldridge, op. cit. 


\section{Empirical Results}

\section{Fractional Logit Analysis on Refugee Outflow}

Results of the fractional logit regression on refugee outflow are reported in Table 2. ${ }^{39)}$ In general, the first hypothesis is supported. UNHCR's expenditure for humanitarian operation inside a country of origin and the presence of international conflict or internal conflict decrease the ratio of refugees from the country. On the other hand, the presence of genocide increases the ratio of refugees that a country produces. Border straightness and ethnic fractionalization are also statistically significant with the increase of the refugee ratio. In contrast to conventional wisdom, the level of humanitarian operation in a bordered country is negatively associated with the ratio of refugees at the .10 significance level. However, UN peacekeeping operations do not hold statistical significance. Hence, the second hypothesis is rejected.

The coefficient estimates of the fractional logit regression can be interpreted using the marginal effect of each variable as reported in Table 3. Marginal effects of continuous variables, such as the log of UNHCR expenditure, the $\log$ of GDP per capita, border straightness, and ethnic fractionalization, are calculated at their mean values, while marginal effects of binary variables are calculated for their discrete change from 0 to 1 . The partial change can be interpreted in terms of percentage by multiplying estimates of $d y / d x$ by 100 .

UNHCR's humanitarian expenditure in the previous year decreases the ratio of refugees from a country of origin by $3.1 \%$ per the one-unit increase of the $\log$ of UNHCR's expenditure. This finding supports the argument that given the higher level of international humanitarian engagement in a country of origin, displaced people are more likely to relocate inside their country. Since 2000, UNHCR has actively involved in forced migration crises to help IDPs. By the end of 2008, more than 50\% of IDPs were assisted by UNHCR operations. Given the occurrence of forced migration in a country, UNHCR

39) This study checked a sample selection problem using the two-step Heckman model and the GLM (general linear model) sample selection model. Yet, the coefficient estimates of the $\lambda$ in both the models have very small $t$-statistics. Therefore, both models fail to reject the null hypothesis. In other words, there is no statistically significant evidence of a sample selection problem, although the possibility of a sample selection problem may arise in conceptualization and theory development. 
Table 2. Proportion of Refugee Outflow

\begin{tabular}{|c|c|c|c|c|}
\hline \multirow{2}{*}{$\begin{array}{l}\text { Variable } \\
\text { Refugee Outflow: Proportion }\end{array}$} & \multicolumn{2}{|c|}{$\begin{array}{c}\text { GLM } \\
\text { Fractional Logit }\end{array}$} & \multicolumn{2}{|c|}{$\begin{array}{l}\text { Zero-Inflated } \\
\text { Beta Regression }\end{array}$} \\
\hline & & & & \\
\hline Log of UNHCR expenditure ${ }_{t-1}$ & $-0.131 *$ & $(0.054)$ & $-0.054^{+}$ & $(0.032)$ \\
\hline UN peacekeeping $t-1$ & -0.138 & $(0.530)$ & -0.081 & $(0.308)$ \\
\hline International conflict & $-1.728 * *$ & $(0.420)$ & $-0.736 * *$ & $(0.278)$ \\
\hline Internal conflict & $-1.151 * *$ & $(0.343)$ & $-0.551 * *$ & $(0.207)$ \\
\hline Genocide/Politicide & $1.759 * *$ & $(0.563)$ & $0.780 *$ & $(0.312)$ \\
\hline State failure & -0.604 & $(0.496)$ & -0.299 & $(0.318)$ \\
\hline Log of GDP per capita & -0.055 & $(0.265)$ & -0.085 & $(0.169)$ \\
\hline Border straightness & $33.119 * *$ & $(12.343)$ & $13.129^{+}$ & $(7.406)$ \\
\hline Ethnic fractionalization & $0.014 *$ & $(0.005)$ & $0.006^{+}$ & $(0.004)$ \\
\hline FM outflow $t-1$ & -0.348 & $(0.325)$ & -0.098 & $(0.193)$ \\
\hline Log of UNHCR expenditure (NB $\left.{ }_{t-1}\right)$ & $-0.124^{+}$ & $(0.074)$ & -0.035 & $(0.049)$ \\
\hline UN peacekeeping $\left(\mathrm{NB}_{t-1}\right)$ & 0.025 & $(0.301)$ & -0.023 & $(0.197)$ \\
\hline International conflict (NB) & -0.019 & $(0.348)$ & 0.037 & $(0.220)$ \\
\hline Internal conflict (NB) & 0.198 & $(0.349)$ & 0.144 & $(0.213)$ \\
\hline Genocide/Politicide (NB) & $1.271 * *$ & $(0.430)$ & $0.454^{+}$ & $(0.253)$ \\
\hline State failure (NB) & 0.353 & $(0.331)$ & 0.109 & $(0.221)$ \\
\hline Log of GDP per capita (NB) & 0.594 & $(0.414)$ & 0.297 & $(0.249)$ \\
\hline Constant & -2.241 & $(2.594)$ & -0.977 & $(1.508)$ \\
\hline \multicolumn{5}{|l|}{ Selection: Probit Model } \\
\hline Log of UNHCR expenditure ${ }_{t-1}$ & & & $-0.120 * *$ & $(0.023)$ \\
\hline UN peacekeeping $t-1$ & & & 0.058 & $(0.340)$ \\
\hline International conflict & & & $-1.187 * *$ & $(0.397)$ \\
\hline Internal conflict & & & $-1.215 * *$ & $(0.219)$ \\
\hline Genocide/Politicide & & & $-1.460 * *$ & $(0.461)$ \\
\hline State failure & & & $-0.983 *$ & $(0.441)$ \\
\hline Log of GDP per capita & & & $0.195^{+}$ & $(0.108)$ \\
\hline FM outflow ${ }_{t-1}$ & & & 0.000 & $(0.000)$ \\
\hline Constant & & & 0.880 & $(0.669)$ \\
\hline Number of observations & 251 & & 824 & \\
\hline /ln_phi & & & $-0.750 * *$ & $(0.070)$ \\
\hline Log pseudolikelihood & -135.28 & & & \\
\hline Log likelihood & & & 157.64 & \\
\hline
\end{tabular}

Significance levels: $+<.10,<.05,<.01$; Standard errors in parentheses in the Heckman sample selection model and zero inflate beta regression model; Robust standard errors in parentheses in the GLM sample selection model and GLM fractional logit model; STATA 11.0/IC used. 
Table 3. Marginal Effects on Proportion of Refugee Outflow

\begin{tabular}{l|c|c}
\hline \multicolumn{1}{c|}{ Variable } & dy/dx & Std. Err. \\
\hline Log of UNHCR expenditure $_{t-1}$ & $-0.031^{*}$ & $(0.013)$ \\
\hline UN peacekeeping $t-1$ & -0.033 & $(0.127)$ \\
\hline International conflict & $-0.406^{* *}$ & $(0.085)$ \\
\hline Internal conflict & $-0.270^{* *}$ & $(0.077)$ \\
\hline Genocide/Politicide & $0.323^{* *}$ & $(0.072)$ \\
\hline State failure & -0.147 & $(0.123)$ \\
\hline Log of GDP per capita & -0.013 & $(0.062)$ \\
\hline Border straightness & $7.759 * *$ & $(2.869)$ \\
\hline Ethnic fractionalization & $0.003 *$ & $(0.001)$ \\
\hline FM outflow $t-1$ & -0.082 & $(0.076)$ \\
\hline & & \\
\hline Log of UNHCR expenditure (NB $t-1)$ & $-0.029 *$ & $(0.017)$ \\
\hline UN peacekeeping (NB t-1) & 0.006 & $(0.070)$ \\
\hline International conflict (NB) & -0.005 & $(0.082)$ \\
\hline Internal conflict (NB) & 0.047 & $(0.083)$ \\
\hline Genocide/Politicide (NB) & $0.266^{* *}$ & $(0.077)$ \\
\hline State failure (NB) & 0.081 & $(0.074)$ \\
\hline Log of GDP per capita (NB) & 0.139 & $(0.097)$ \\
\hline
\end{tabular}

Note: For binary variables, $\mathrm{dy} / \mathrm{dx}$ is for discrete change from 0 to 1 .

has conducted its humanitarian operations for 265 out of 327 country years, spending US \$14.8 million on average.

The effect of UNHCR's humanitarian assistance on the refugee outflow can be evaluated in different ways, as in Table 4 . There were 80 new displacements in the 1980 s, 113 in the 1990 s, and 134 in the 2000 s, respectively. This coincides with the increasing number of internal conflict in this region since the mid 1990s. UNHCR was involved in $71.3 \%$ of new displacements during the $1980 \mathrm{~s}, 75.2 \%$ during the $1990 \mathrm{~s}$, and $91.8 \%$ during the $2000 \mathrm{~s}$. This is because UNHCR has expanded its role in assisting and protecting refugees and IDPs in the 2000s. While UNHCR's main concern shifted from African refugees to refugees and IDPs in Eastern Europe in the mid-1990s, its concern about African refugees and IDPs has grown since the late 1990s when the international community began to pay much attention to IDP crises worldwide. Therefore, the refugee ratio in the 1990s decreased because more IDPs were produced, and those IDPs were assisted by UNHCR. However, 
average UNHCR expenditures in a country of origin have decreased during the 2000s so that displaced people have to survive with a lack of resources. Consequently host governments become reluctant to receive refugees.

Table 4. Comparison of UNHCR's Engagement and Refugee Outflow by Decades

\begin{tabular}{l|c|c|c|c|c|c|c|c}
\hline & \multicolumn{3}{|c|}{$\begin{array}{c}\text { Forced Migrants Flows } \\
\text { with All Observations }\end{array}$} & \multicolumn{3}{c}{$\begin{array}{c}\text { Forced Migrants Flows } \\
\text { with UNHCR's Engagement }\end{array}$} \\
\cline { 2 - 10 } & $\mathbf{1 9 8 0 s}$ & $\mathbf{1 9 9 0 s}$ & $\mathbf{2 0 0 0 s}$ & total & $\mathbf{1 9 8 0 s}$ & $\mathbf{1 9 9 0 s}$ & $\mathbf{2 0 0 0 s}$ & total \\
\hline Ratio of Refugees & 0.71 & 0.52 & 0.57 & 0.59 & 0.73 & 0.48 & 0.54 & 0.56 \\
\hline Observations & 80 & 113 & 134 & 327 & 57 & 85 & 123 & 265 \\
\hline Average UNHCR's Expenditure & 11.6 & 13.5 & 11.9 & 12.4 & 16.3 & 17.9 & 13.0 & 15.3 \\
\hline
\end{tabular}

Note: One-year-lagged UNHCR's expenditure in US \$1 million.

Contrary to the conventional expectation, the presence of international conflict decreases the proportion of refugees among forced migrants by $40.6 \%$. In the sample, there are 56 observations in which international conflict took place in a country of origin. The countries produced on average 333,000 new IDPs and 82,300 new refugees in a given year in the presence of international conflict. On the other hand, countries produced on average 121,000 new IDPs and 27 new refugees during 271 country years without international conflict.

International conflict, substantively speaking, produced more refugees but also many more IDPs. The refugee ratio of forced migrants that a country produced in international conflict is on average 0.39 , as compared to 0.63 in the absence of international conflict. UNHCR operated humanitarian works in $83.9 \%$ of observations that included international conflict. UNHCR did not provided humanitarian assistance and protection in the international conflict in Chad (1981, 1984-85, 1997, and 1999), Guinea-Bissau (1998), and Mozambique (1985 and 1987-88). The amount of its humanitarian expenditure is not significantly different regardless of the occurrence of international conflict.

The occurrence of internal conflict decreases the ratio of refugees by $27.0 \%$. In the sample, internal conflict took place for 133 out of 327 country years. Countries under internal conflict produced on average 217,000 IDPs and 42,000 refugees in a given year, while countries without internal conflict produced on average 115,000 IDPs and 33,000 refugees. In other words, 
internal conflict produced more refugees, but it also produced many more IDPs. Therefore, the mean value of refugee outflow decreased from 0.64 to 0.50 as internal conflict occurred.

Genocide and politicide increased the refugee ratio by $32.3 \%$. As other studies show, organized political violence by a government targeting a specific group increases the expected threat of being victimized among people within that group. Thus, displaced people are more likely to seek refuge outside their country of origin. In addition, neighboring countries are likely to open their borders in the incident of genocide and politicide in the country of origin. UNHCR provided humanitarian assistance and protection in a previous year in $82.8 \%$ of internal conflicts, which is about $3 \%$ more than other observations.

Countries of which borderlines are straighter produced more refugees. Displaced people can easily cross international borders if borderlines were drawn straightly. ${ }^{40)}$ Put differently, they have opportunities to cross borders with less travel costs. On the other hand, ethnic fractionalization is statistically significant, but its marginal effect is only $0.3 \%$. The presence of ethnic diaspora in neighboring countries is expected to pull displaced people. However, because of that possibility, host governments in sub-Saharan Africa have securitized refugees and adopted very restrictive containment policies toward people moving from countries of origin.

The relationship between neighborhood variables and the proportion of refugee outflow does not support expectations. UNHCR's humanitarian operations in a bordered country hold statistical significance at the .10 level, decreasing the ratio of refugees by $2.9 \%$ as a one-unit of UNHCR's expenditure increases. The role of humanitarian response as a pull factor can hardly be demonstrated because most refugee sending countries in subSaharan African countries are hosting refugees from bordered countries.

The occurrence of genocide and politicide in neighboring countries increases the ratio of refugee outflow. This may be because genocide and politicide in a country often have a spill-over effect due to the ethnic complexity. For only $32.9 \%$ of country years, countries that are bordered by at least one country under genocide and politicide had not been affected by

40) Alberto Alesina et al., "Artificial States," Journal of European Economic Association 9-2 (2011), pp. 246-277. 
conflict in their territory. So, the existence of genocide and politicide in a bordered country may deter displaced people from moving into that neighboring country, but it does not prevent displaced people from moving into other neighboring countries.

\section{Fractional Logit Analysis on Refugee Inflow}

Results of the fractional logit regression on refugee inflow are reported in Table 5. In general, UNHCR's expenditures for humanitarian works and UN peacekeeping operations inside a country of asylum do not hold statistical significance. On the other hand, the presence of international conflict, internal conflict, or state failure decreases the ratio of refugee inflow. Border straightness is positively associated with the ratio of refugee inflow, while ethnic fractionalization is not statistically significant. The level of humanitarian operations in a bordered country is not statistically significant. The occurrence of genocide and politicide in neighboring countries increase refugee inflow.

The marginal effect of each variable is reported in Table 6. Similar to Table 3 , marginal effects of continuous variables, including the log of UNHCR expenditure, the log of GDP per capita, border straightness, and ethnic fractionalization, are calculated at their mean values, while marginal effects of binary variables are calculated for their discrete change from 0 to 1 . The marginal effects can be interpreted using the percentage calculated by multiplying estimates of $d y / d x$ by 100 .

According to the results, the third and fourth hypotheses are not supported. UNHCR's humanitarian works and UN peacekeeping do not play as pulling factors in forced migration crises in terms of the ratio of refugees residing in a country of origin. UNHCR involved in $77 \%$ of forced migration crises, and the mean value of refugee inflow in those cases increased by $6 \%$. However, its impact is not statistically significant. UN peacekeeping was operated in 9.5\% of forced migration crises. Even though it does not hold statistical significance, it decreased the ratio of refugee inflow from $71.0 \%$ to $41.8 \%$. This is because UNHCR and UN peacekeeping operations in contemporary forced migration crises are associated with IDPs rather than refugees.

The presence of violent conflict in a country of asylum becomes a preventive factor that influences the decision for displaced people to not 
Table 5. Proportion of Refugee Inflow

\begin{tabular}{|c|c|c|c|c|}
\hline \multirow{2}{*}{$\begin{array}{c}\text { Variable } \\
\text { Refugee Outflow: Proportion }\end{array}$} & \multicolumn{2}{|c|}{$\begin{array}{c}\text { GLM } \\
\text { Fractional Logit }\end{array}$} & \multicolumn{2}{|c|}{$\begin{array}{l}\text { Zero-Inflated } \\
\text { Beta Regression }\end{array}$} \\
\hline & & & & \\
\hline Log of UNHCR expenditure ${ }_{t-1}$ & -0.064 & $(0.051)$ & -0.016 & $(0.023)$ \\
\hline UN peacekeeping $t_{t-1}$ & -0.764 & $(0.567)$ & -0.289 & $(0.284)$ \\
\hline International conflict & $-3.156 * *$ & $(0.552)$ & $-1.314 * *$ & $(0.276)$ \\
\hline Internal conflict & $-1.525 * *$ & $(0.383)$ & $-0.636 * *$ & $(0.186)$ \\
\hline Genocide/Politicide & $0.168^{*}$ & $(0.605)$ & -0.205 & $(0.303)$ \\
\hline State failure & -1.698 & $(0.720)$ & $-0.785^{*}$ & $(0.324)$ \\
\hline Log of GDP per capita & 0.116 & $(0.277)$ & 0.013 & $(0.135)$ \\
\hline Border straightness & $31.776^{* *}$ & $(11.303)$ & 8.482 & $(6.177)$ \\
\hline Ethnic fractionalization & 0.007 & $(0.006)$ & 0.003 & $(0.003)$ \\
\hline FM outflow $t-1$ & 0.639 & $(0.299)$ & 0.192 & $(0.151)$ \\
\hline Log of UNHCR expenditure $\left(\mathrm{NB}_{t-1}\right)$ & -0.098 & $(0.068)$ & -0.032 & $(0.034)$ \\
\hline UN peacekeeping $\left(\mathrm{NB}_{t-1}\right)$ & -0.324 & $(0.331)$ & -0.148 & $(0.175)$ \\
\hline International conflict (NB) & 0.518 & $(0.356)$ & 0.193 & $(0.166)$ \\
\hline Internal conflict (NB) & 0.204 & $(0.348)$ & 0.106 & $(0.166)$ \\
\hline Genocide/Politicide (NB) & $0.912 *$ & $(0.388)$ & 0.310 & $(0.197)$ \\
\hline State failure (NB) & -0.011 & $(0.323)$ & -0.027 & $(0.170)$ \\
\hline Log of GDP per capita (NB) & 0.354 & $(0.436)$ & 0.100 & $(0.209)$ \\
\hline Constant & -1.702 & $(2.209)$ & 0.012 & $(1.027)$ \\
\hline \multicolumn{5}{|l|}{ Selection: Probit Model } \\
\hline Log of UNHCR expenditure $t-1$ & & & $-0.133 * *$ & $(0.019)$ \\
\hline UN peacekeeping $t-I$ & & & 0.303 & $(0.307)$ \\
\hline International conflict & & & $-1.100 * *$ & $(0.365)$ \\
\hline Internal conflict & & & $-0.819 * *$ & $(0.210)$ \\
\hline Genocide/Politicide & & & 0.059 & $(0.366)$ \\
\hline State failure & & & -0.148 & $(0.400)$ \\
\hline Log of GDP per capita & & & 0.063 & $(0.085)$ \\
\hline FM outflow ${ }_{t-1}$ & & & 0.000 & $(0.000)$ \\
\hline Constant & & & 0.820 & $(0.535)$ \\
\hline Number of observations & 354 & & 824 & \\
\hline /ln_phi & & & $-0.640 * *$ & $(0.064)$ \\
\hline Log pseudolikelihood & -147.85 & & & \\
\hline Log likelihood & & & 450.66 & \\
\hline
\end{tabular}

Significance levels: $+<.10,<.05,<.01$; Standard errors in parentheses in the Heckman sample selection model and zero inflate beta regression model; Robust standard errors in parentheses in the GLM sample selection model and GLM fractional logit model; STATA 11.0/IC used. 
Table 6. Marginal Effects on Refugee Inflow

\begin{tabular}{l|c|c}
\hline \multicolumn{1}{c|}{ Variable } & dy/dx & Std. Err. \\
\hline Log of UNHCR expenditure (t-1) & -0.012 & $(0.009)$ \\
\hline UN peacekeeping (t-1) & -0.162 & $(0.133)$ \\
\hline International conflict & $-0.655^{* *}$ & $(0.073)$ \\
\hline Internal conflict & $-0.316^{* *}$ & $(0.081)$ \\
\hline Genocide/Politicide & 0.030 & $(0.104)$ \\
\hline State failure & $-0.389^{*}$ & $(0.169)$ \\
\hline Log of GDP per capita & 0.021 & $(0.051)$ \\
\hline Border straightness & $5.883^{* *}$ & $(2.075)$ \\
\hline Ethnic fractionalization & 0.001 & $(0.001)$ \\
\hline FM outflow (t-1) & 0.118 & $(0.056)$ \\
\hline & & \\
\hline Log of UNHCR expenditure (NB t-1) & -0.018 & $(0.013)$ \\
\hline UN peacekeeping (NB t-1) & -0.062 & $(0.066)$ \\
\hline International conflict (NB) & 0.092 & $(0.059)$ \\
\hline Internal conflict (NB) & 0.038 & $(0.066)$ \\
\hline Genocide/Politicide (NB) & $0.150^{* *}$ & $(0.056)$ \\
\hline State failure (NB) & -0.002 & $(0.060)$ \\
\hline Log of GDP per capita (NB) & 0.066 & $(0.081)$ \\
\hline Not For bing & &
\end{tabular}

Note: For binary variables, dy/dx is for discrete change from 0 to 1 .

move into the country. The international conflict in an asylum country decreased the ratio of refugee inflow by $65.5 \%$; internal conflict decreased the ratio of refugee inflow by $31.6 \%$; and failed governance decreased the proportion of refugees newly coming to an asylum country by $38.9 \%$. As discussed in the previous section, most sub-Saharan African countries displace people and host refugees at the same time. The study consistently finds that a decrease in the proportion of refugee inflow resulted from an increase of IDPs in a country of asylum.

Border straightness increases the share of refugees of forced migrants who reside in a country of asylum. This mirrors the finding in the previous section that border straightness increases the ratio of refugee outflow. Yet, ethnic fractionalization is not statistically significant. This study also finds that the level of refugee inflow in a previous year increased the ratio of refugee inflow by $11.8 \%$. In this study, variables of neighboring countries, except genocide and politicide, are statistically insignificant, contrary to 
expectations. The occurrence of genocide and politicide in neighboring countries increased the proportion of refugee inflow in an asylum country.

\section{Conclusion}

Population displacement has changed as the nature of warfare has changed. Since the late 1970s, most proxy wars in the East-West conflict occurred within a country's territory, which implies that most of the forced migrants were IDPs rather than refugees. In addition, since the end of the Cold War, accepting refugees has provided no political gains to host countries, especially when they come from the poorest of countries. As a result, asylum policies have become very restrictive as "the end of the Cold War swept away any remaining ideological motive for accepting refugees." ${ }^{41)}$ Superpowers were reluctant to get involved in the politics in sub-Saharan Africa in the 1990s. Governments and armed groups have targeted civilians in internal conflict; consequently, refugee numbers continued to fall, but IDP numbers continued to rise. Hence, the international community has developed international institutional frameworks to assist and protect IDPs when governments are unwilling and/or unable to fulfill their responsibilities to their citizens.

This evolution of refugee and IDP protection regimes and international responses to forced migration recall Reinhold Niebuhr's reflection on politics: "[p]olitics will, to the end of history, be an arena where conscience and power meet, where the ethical and coercive factors of human life will interpenetrate and work out their tentative and uneasy compromises." ${ }_{42}$ The realist tradition has commonly regarded forced migration as an international phenomenon of interest only if it has significant implications on the quest for security as well as the accumulation of power and force. However, growing normative concerns among the international community at domestic and international levels have facilitated international cooperation to help refugees

41) Human Security Center, Human Security Report 2005 (New York: Oxford University Press, 2005), p. 104.

42) Reinhold Niebuhr, Moral Man and Immoral Society: A Study in Ethics and Politics (New York: C. Scribner's Sons, 1932), p. 5. 
and IDPs. The international community has well recognized the principle of state sovereignty as long as states fulfill widely accepted international moral obligations, but it has frequently become involved in forced migration crises in countries of origin when governments did not fulfill their obligations to protect their citizens' human rights.

Therefore, this study viewed forced migrants such as refugees and IDPs, as political actors who influence and are influenced by processes and outcomes of forced migration. Forced migrants make provisional decisions, with constrained freedom of choice, about whether to leave home and whether to cross international borders. They do not always respond in the same way to the same root causes. They make their decisions based on both their expectation that they will be victimized and their expectation that they will be protected by the international community. For this study, forced migration was thus considered a graded concept that can be analyzed through the lens of a conceptual continuum with the ends of total migration and non-migration.

This study examined the impact that international humanitarian response has on the ratio of refugees to total forced migrants. It found that the higher level of UNHCR's humanitarian engagement in a country of origin decreases the ratio of refugees to forced migrants that the country produces. UNHCR's humanitarian work does not hold statistical significance in its relationship to refugee inflow. The impact of UN peacekeeping operations on refugee inflow and outflow are not statistically significant. This results from the fact that UNHCR and UN peacekeeping operations in contemporary forced migration crises are associated with more IDPs than refugees. UNHCR and UN peacekeeping used to focus on refugee assistance and protection, but their mandate has been expanded to help IDPs since the late 1990s.

The findings are mixed, but this study has provided implications for international relations and forced migrations studies. First, states respond to forced migration very selectively. From the realist perspective, states' engagement with forced migration happens only if the states would have broader interests in providing assistance and protection. For instance, since the early 1990s, the number of refugees in the world has decreased while the number of IDPs has increased. The decreasing number of refugees does not result from the decreasing number of forced migrants, but it results from the restrictive refugee policies of host governments. Instead of recognizing new displaced people as refugees, host governments return those displaced people 
to their countries of origin and/or confine them along countries' borders. Host governments have actively engaged with refugees only if their political and economic interests are at stake. Therefore, in 2008, the ratio of the number of IDPs to the number of refugees in sub-Saharan Africa reached 5.5:1.

Second, since the early 1990s, the international community has begun paying attention to IDP crises for reasons of mutual self-interest. The fundamental responsibilities for IDP assistance and protection are under the governments of the countries of origin. But what is important for human rights bodies to address is what should happen when governments do not meet their responsibilities to IDPs. All of the top-15 IDP-producing countries are the least developed countries, and most forced internal displacements in the past decade were caused by internal armed conflict. In addition, a great number of IDPs impose much financial burden on the government, and if IDPs are not provided with enough resources and/or protection services, they are likely to become involved in military actions voluntarily or involuntarily. Thus, states agreed to the Guiding Principle to address IDP crises so that IDP issues would not become threats to their national security.

Third, the attitude of the incumbent government shapes its responses to forced migration. In sub-Saharan Africa during the 1970s and 1980s, for example, Kenya and Tanzania had reputations for being the most generous asylum states in Africa, but since the late 1990s, the Kenyan and Tanzanian governments have adopted more restrictive asylum policies as international support has decreased. Nevertheless, more than $80 \%$ of displaced people from sub-Saharan African countries have stayed in the region. The increasing proportion of intrastate and/or intraregional movement reflects that Western democracies do not want to host sub-Saharan African refugees while they provide humanitarian resources for UNHCR and other international humanitarian organizations.

Fourth, state sovereignty should not be considered an unchangeable concept. It may be limited by the emerging concept of "responsibility of protection." Although the concept to balance the respect of state sovereignty with the responsibility to protect states' needy citizens is controversial, the following idea is gaining more attention among researchers and practitioners in world politics: 
the protection of its people lies with the state itself. Where a population is suffering serious harm, as a result of internal war, insurgency, repression or state failure, and the state in question is unwilling or unable to halt or avert it, the principle of non-intervention yields to the international responsibility to protect. ${ }^{43)}$

As a result, more than $50 \%$ of the total number of IDPs were assisted by UNHCR involved humanitarian operations in 2007. A pure state-centric approach, with the traditional concept of state sovereignty, risks ignoring the role of weak governments, armed groups, international trade groups whose investment is mainly concentrated on primary resources, and international organizations in shaping the politics of forced migration.

Given the restrictive containment refugee policy, which is preferred by most governments in sub-Saharan Africa, the lives of IDPs and refugees become more dependent on international assistance and protection. However, humanitarian emergencies cannot be solved only by humanitarian imperatives. Most governments in sub-Saharan African countries have politicized and securitized issues related to refugees and IDPs, and they have conceded the responsibility to protect refugees and IDPs to international humanitarian organizations such as UNHCR. Thus, the international humanitarian organizations should expand the scope of their operation to assist IDPs and draw political cooperation from national governments to provide durable solutions to forced migration crises.

\section{REFERENCES}

Adelman, Howard and Susan McGrath. "To Date or To Marry: That is the Question.” Journal of Refugee Studies 20-3. 2007, pp. 376-380.

Alesina, Alberto, William Easterly, and Janina Matuszeski. "Artificial States." Journal of European Economic Association 9-2. 2011, pp. 246-277.

Arendt, Hannah. The Origins of Totalitarianism. New York: Harcourt, 1966. Azam, Jean-Paul and Anke Hoeffler. "Violence against Civilians in Civil Wars:

43) International Commission on Intervention and State Sovereignty (ICISS), The Responsibility to Protect, a report of International Commission on Intervention and State Sovereignty (Ottawa, Canada: International Development Research Center, 2001), p. xi. 
Looting or Terror?" Journal of Peace Studies 39-4. 2002, pp. 461-485. Ball, Patrick, Wendy Betts, Fritz Scheuren, Jana Dudukovic, and Jana Asher. "Killings and Refugee Flow in Kosovo, March-June 1999: Analysis and Conclusions." Report to the International Criminal Tribunal for the Former Yugoslavia. Washington, DC: American Association for the Advancement of Science, 2002.

Brehm, John and Scott Gates. "Donut Shops and Speed Traps: Evaluating Models of Supervision on Police Behavior." American Journal of Political Science 37-2. 1993, pp. 551-581.

Castells, Manuel. The Rise of the Network Society. Cambridge, Massachusetts: Blackwell Publishers, 1996.

Chimni, B. S. "The Birth of a 'Discipline': From Refugee to Forced Migration Studies.” Journal of Refugee Studies 22-1. 2009, pp. 11-29.

Cohen, Roberta and Francis M. Deng. Masses in Flight: The Global Crisis of Internal Displacement. Washington, DC: Brookings Institution Press, 1998.

Davenport, Christian A., Will H. Moore, and Steven C. Poe. "Sometimes You Just Have to Leave: Domestic Threats and Forced Migration, 19641989." International Interactions 29-1. 2003, pp. 27-55.

Donnelly, Jack. Universal Human Rights in Theory and Practice. 2nd Ed. Ithaca, New York: Cornell University Press, 2003.

Dowty, Alan and Gil Loescher. "Refugee Flows as Grounds for International Actions." International Security 21-1. 1966, pp. 43-71.

Gibney, Matthew J. The Ethics and Politics of Asylum: Liberal Democracy and the Response to Refugees. New York: Cambridge University Press, 2004.

Gleditsch, Nils Petter, Peter Walensteen, Mikael Erikson, Margareta Sollenberg, and Håvard Strand. "Armed Conflict 1946-2001: A New Dataset." Journal of Peace Research 39-5. 2002, pp. 615-637.

Haddad, Emma. The Refugee in International Society: Between Sovereigns. New York: Cambridge University Press, 2008.

Hakovirta, Harto. Third World Conflict and Refugeeism. Helsinki, Finland: The Finnish Society of Science and Letters, 1986.

Harff, Barbara. "No Lessons Learned from the Holocaust? Assessing the Risks of Genocide and Political Mass Murder Since 1955." American Political Science Review 97-1. 2003, pp. 57-74.

Hathaway, James C. "Forced Migration Studies: Could We Agree Just to Date?" Journal of Refugee Studies 20-3. 2007, pp. 349-369. 
Hayden, Bridget. "What's in a Name? The Nature of the Individual in Refugee Studies." Journal of Refugee Studies 19-4. 2006, pp. 471-487.

Hirschman, Albert O. Exit, Voice, and Loyalty: Responses to Decline in Firms, Organizations, and States. Cambridge, Massachusetts: Harvard University Press, 1970.

Human Security Centre. Human Security Report 2005. New York: Oxford University Press, 2005.

Internal Displacement Monitoring Centre. Internal Displacement: Global Overview of Trends and Developments in 2009. Geneva, Switzerland: Internal Displacement Monitoring Centre \& Norwegian Refugee Council, 2010.

International Commission on Intervention and State Sovereignty. The Responsibility to Protect. Report of International Commission on Intervention and State Sovereignty. Ottawa, Canada: International Development Research Centre, 2001.

Iqbal, Zaryab. "The Geo-Politics of Forced Migration in Africa, 1992-2001." Conflict Management and Peace Science 24-2. 2007, pp. 105-119.

Iqbal, Zaryab and Harvey Starr. "Bad Neighbors: Failed States and Their Consequences." Conflict Management and Peace Science 25-4. 2008, pp. 105-109.

Kalyvas, Stathis N. The Logic of Violence in Civil Wars. New York: Cambridge University Press, 2006.

Kaufman, Chaim D. Intervention in Ethnic, Ideological, and Colonial Wars: Opportunities, Options, and Constraints. Reston, Virginia: Sherman Kent School for Intelligence Analyses, 2004.

Lichbach, Mark Irving. The Rebel's Dilemma. Ann Arbor, Michigan: The University of Michigan Press, 1995.

Lischer, Sarah Kenyon. "Collateral Damage: Humanitarian Assistance as a Cause of Conflict.” International Security 28-1. 2003, pp. 79-109. . Dangerous Sanctuaries: Refugee Camps, Civil War, and the Dilemmas of Humanitarian Affairs. Ithaca, New York: Cornell University Press, 2005.

Loescher, Gil. Beyond Charity: International Cooperation and the Global Refugee Crisis. New York: Oxford University Press, 1993.

Massey, Douglas S., Joaquin Arango, Graeme Hugo, Ali Kouaouci, Adela Pellegrino, and J. Edward Taylor. "Theories of International Migration: A Review and Appraisal." Population and Development Review 19-3. 1993, pp. 431-466. 
Mebane, Walter R. "Coordination, Moderation, and Institutional Balancing in American Presidential and House Election." American Political Science Review 94-1. 2000, pp. 37-57.

Moore, Will H. and Stephen M. Shellman. "Fear of Persecution: Forced Migration, 1952-1995." Journal of Conflict Resolution 43-5. 2004, pp. 723-745.

. "Refugee or Internally Displaced Person? To Where Should One Flee?" Comparative Political Studies 39-5. 2006, pp. 599-633.

Morrison, Andrew R. and Rachel A. May. "Escape from Terror: Violence and Migration in Post-Revolutionary Guatemala." Latin American Research Review 29-2. 1994, pp. 111-133.

Nahm, Sue J. "Rebels, Refugees, and War: Militarized Camps and Its Implications for Humanitarian Assistance in Time of War." Paper presented at the Annual Convention of the International Studies Association. Chicago, Illinois, USA. 28 February-3 March 2007.

Neumayer, Eric. "Bogus Refugees? The Determinants of Asylum Migration to Western Europe." International Studies Quarterly 49-3. 2005, pp. 384409.

Niebuhr, Reinhold. Moral Man and Immoral Society: A Study in Ethics and Politics. New York: C. Scribner's Sons, 1932.

Palmquist, Bradley. "Analysis of Proportions Data." Paper presented at the 1999 Annual Meeting of the Political Methodology Society. College Station, Texas, USA. 1999.

Paolino, Philip. "Maximum Likelihood Estimation of Models with BetaDistributed Dependent Variables." Political Analysis 9-4. 2001, pp. 325346.

Papke, Leslie E. and Jeffrey M. Wooldridge. "Econometric Methods for Fractional Response Variables with an Application to 401(k) Plan Participation Rates." Journal of Applied Econometrics 11-6. 1996, pp. 619-632.

Phuong, Catherine. The International Protection of Internally Displaced Persons. New York: Cambridge University Press, 2004.

Powell, G. Bingham. "American Voter Turnout in Comparative Perspective." American Political Science Review 80-1. 1986, pp. 17-43.

Roper, Steven D. and Lilian A. Barria. "Burden Sharing in the Funding of the UNHCR: Refugee Protection as an Impure Public Good." Journal of Conflict Resolution 54-4. 2010, pp. 616-637.

Rummel, Rudolph J. Statistics of Democide: Genocide and Mass Murder 
Since 1990. New Brunswick, New Jersey: Transaction Book, 1998.

Salehyan, Idean. "Transnational Rebels: Neighboring States as Sanctuary for Rebel Groups." World Politics 59-2. 2007, pp. 221-242.

Schmeidl, Susanne. "Exploring the Causes of Forced Migration: A Pooled Time-Series Analysis, 1971-1990." Social Science Quarterly 78-2. 1997, pp. 284-308.

Starr, Harvey. "Introduction to the CMPS Special Issue on Failed States." Conflict Management and Peace Science 25-4. 2008, pp. 281-284.

Stedman, Stephen John and Fred Tanner. Refugee Manipulation: War, Politics, and the Abuse of Human Suffering. Washington, DC: Brookings Institution Press, 2003.

United Nations High Commissioner for Refugees (UNHCR). UNHCR Statistical Yearbook 2009. Geneva, Switzerland: United Nations High Commissioner for Refugees, 2010.

Van Hear, Nicholas. New Diasporas: The Mass Exodus, Dispersal and Regrouping of Migrant Communities. Seattle, Washington: University of Washington Press, 1998.

Väyrynen, Raimo. "Funding Dilemmas in Refugee Assistance: Political Interests and Institutional Reforms in UNHCR." International Migration Review 35-1. 2010, pp. 143-167.

Walzer, Michael. Spheres of Justice. New York: Basic Books, 1983.

Weiner, Myron. "Security, Stability, and International Migration." International Security 17-3. 1992, pp. 91-126.

. "Bad Neighbors, Bad Neighborhoods: An Inquiry into the Causes of Refugee Flows." International Security 21-2. 1996, pp. 5-42.

Weiss, Thomas G. and David A. Korn. Internal Displacement: Conceptualization and Its Consequences. New York: Routledge, 2006.

Wooldridge, Jeffrey M. Econometric Analysis of Cross Section and Panel Data. Cambridge, Massachusetts: MIT Press, 2002. 